\title{
Management of Meloidogyne javanica in Okra Using Compost of Pequi Fruit Waste
}

\author{
Fabíola de Jesus Silva ${ }^{1}$, Regina Cássia Ferreira Ribeiro ${ }^{2}$, Adelica Aparecida Xavier ${ }^{2}$, José Augusto Santos Neto ${ }^{2}$, \\ Cláudia Maria da Silva ${ }^{3} \&$ Edson Hiydu Mizobutsi ${ }^{2}$ \\ ${ }^{1}$ Federal University of Lavras, Lavras, Brazil \\ ${ }^{2}$ State University of Montes Claros, Janaúba, Brazil \\ ${ }^{3}$ Federal University of Vale do Jequitinhonha e Mucuri, Janaúba, Brazil \\ Correspondence: Regina Cássia Ferreira Ribeiro, State University of Montes Claros, Janaúba, Brazil. E-mail: \\ recafe@bol.com.br
}

Received: March 22, 2018

Accepted: May 1, $2018 \quad$ Online Published: June 15, 2018

doi:10.5539/jas.v10n7p258

URL: https://doi.org/10.5539/jas.v10n7p258

\begin{abstract}
Pequi waste added to soil can lead to promising results in the management of plant nematodes. This study evaluated the effect of organic compost of pequi fruit waste in the control of Meloidogyne javanica in okra plants. The compost was comprised of cattle manure, sugarcane straw, and pequi rind waste in the ratio 1:1:1. Treatments were five doses of organic compost $\left(0,5,10,20\right.$, and $\left.30 \mathrm{~g} \mathrm{dm}^{-3}\right)$ and two additional controls: manure $\left(20 \mathrm{~g} \mathrm{dm}^{-3}\right)$ and mineral fertilizer $\left(100 \mathrm{mg} \mathrm{dm}^{-3}\right.$ of $\left.\mathrm{N}\right)$, arranged in randomized block design with 10 repetitions. Different treatments were incorporated into pots containing $3 \mathrm{dm}^{-3}$ of sandy soil infested with 5,000 eggs of $M$. javanica. Seedlings were transplanted five days later, and evaluated after 60 days of transplanting. Organic compost with pequi waste incorporated to soil increased shoot dry weight and root weight, and reduced the number of egg masses, galls and eggs of M. javanica per gram of root, and reproduction factor. Doses of 20 and $30 \mathrm{~g} \mathrm{dm}^{-3}$ increased plant development and reduced the reproductivity of $M$. javanica compared to mineral fertilizer.
\end{abstract}

Keywords: Abelmoschus esculentus, Caryocar brasiliense, root-knot nematode, organic matter

\section{Introduction}

Okra (Abelmoschus esculentus L.) is a vegetable grown throughout the year in warm regions at relatively low cost, which is often a good alternative source of farmers' income (Oliveira et al., 2007). However, okra susceptibility to nematodes belonging to the Meloidogyne genus is a limiting factor to production. Nematodes significantly reduces okra yield and may result in abandonment of the crop (Campos, 1995). These plant pathogens are difficult to control due to their high reproductive capacity and polyphagous habit, and lack of resistant cultivars and registered nematicides.

Accounting for the aforementioned practical limitations, organic composts are an alternative in management of plant nematodes. Various agricultural waste and agro-products have shown potential for plant nematode control when incorporated into soil, especially after composting (Davi \& Das, 2016; Sahu et al., 2018). Upon decomposition, many changes occur in the material, leading to release of composts that may be toxic to nematodes (Oka, 2010). Various bioactive nematicides have been described in the literature, such as glucosinolates in Brassica species, azadirachtin in neem (Azadirachta indica), and composts released from waste of Tagetes spp. and Mucuna spp. (Neves et al., 2007; Osei et al., 2010; Nile et al., 2018). Studies show that phenolic composts and tannins released from plants also feature nematicide activity (Naz et al., 2013; Reiner, 2015; Khan et al., 2017). In addition to direct involvement in nematode control, the organic matter can improve physical and chemical characteristics of the soil and increase the population of microorganisms antagonistic to nematodes (Giné et al., 2013; Luambano et al., 2015).

Large amounts of waste are produced in the North of the state of Minas Gerais - Brazil during harvest and marketing process of pequi fruit (Caryocar brasiliense Camb.). Although fruit is large and bulky, only $10 \%$ of total weight is edible pulp while the remainder is seed and peel, which is rich in phenolic composts, tannins, sugars, and other substances (Plácido et al., 2015). The pequi waste dried and ground has been comproved to 
control Meloidogyne javanica, but it was toxic to tomato plants (Ribeiro et al., 2012). Composting of pequi waste may be viable because various chemicals compounds may degrade during compost stabilization, thus causing no phytotoxicity (Ait Baddi et al., 2004). This alternative could be economic, social, and ecological because the fruit is regional and easy to purchase. In addition, there is no correct destination for pequi waste disposal on the environment so far. Thus, this study evaluated the effect of pequi waste organic compost on the control of $M$. javanica and development of okra plants.

\section{Materials and Methods}

The experiment was conducted in a greenhouse at the State University of Montes Claros (UNIMONTES). For the preparation of pequi waste organic compost, we selected fruit for consumption without any damage. Fruits were washed and cut to obtain the epicarp (peel) and mesocarp (pulp), which were picked manually in $2.5 \mathrm{~cm}$ fragments. The compost pile was comprised of manure, sugarcane straw, pequi peel, and mesocarp in the ratio of $1: 1: 1$. The mixing ratio was determined to bring the $\mathrm{C} / \mathrm{N}$ ratio closer to approximately $30 / 1$ before composting, as suggested by Kiehl (1985). Windrows were mounted in conical shape with $0.6 \mathrm{~m}$ height and $0.8 \mathrm{~m}$ inclination. Piles were turned weekly and water was added when necessary to keep the compost moist. The organic compost was considered humidified and ready for use when showing typical physical characteristics of maturation (about 60 days of composting). A compost sample was sent to the laboratory of organic matter at the Federal University of Viçosa for chemical analysis of macro and micronutrients and humic fractions (Table 1).

Table 1. The chemical composition of the organic compost

\begin{tabular}{|c|c|c|c|c|c|c|c|}
\hline \multicolumn{8}{|c|}{ Data based on the dry matter ( $65 \%$ humidity) } \\
\hline $\mathrm{C}$ & $\mathrm{N}$ & $\mathrm{P}$ & $\mathrm{K}$ & & $\mathrm{Ca}$ & $\mathrm{Mg}$ & $\mathrm{S}$ \\
\hline \multicolumn{8}{|c|}{ 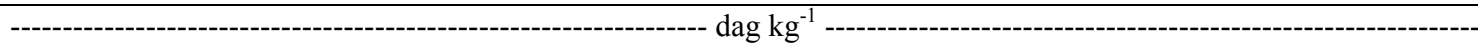 } \\
\hline 16.7 & 1.41 & 0.67 & 0.63 & & 3.42 & 0.41 & 2.06 \\
\hline $\mathrm{Cu}$ & $\mathrm{Zn}$ & $\mathrm{Mn}$ & $\mathrm{Fe}$ & $\mathrm{NH}_{4}^{+}$ & $\mathrm{NO}_{3}^{-}$ & $\mathrm{AH}$ & $\mathrm{AF}$ \\
\hline \multicolumn{8}{|c|}{ 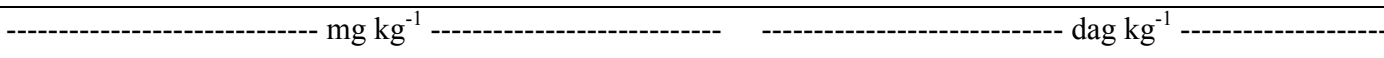 } \\
\hline 45.80 & 195.30 & 290.70 & 3398.00 & 37.84 & 0.58 & 0.47 & 0.38 \\
\hline
\end{tabular}

Note. Analyses performed by the Organic Matter and Waste Laboratory, Department of Soil Science of the Federal University of Viçosa. AH: humic acid; AF: fulvic acid.

We used five doses of organic compost: $0,5,10,20$, and $30 \mathrm{~g} \mathrm{dm}^{-3}$. Two additional treatments consisting of manure at $20 \mathrm{~g} \mathrm{dm}^{-3}$ and nitrogen at $100 \mathrm{mg} \mathrm{dm}^{-3}$ in the form of urea were also evaluated. The experimental design was a randomized block with ten replicates per treatment.

We used pots for $3 \mathrm{dm}^{-3}$ of soil in the beginning of the experiment. Sandy soil (9\% clay) was collected at $0-20$ $\mathrm{cm}$ depth, and had the following chemical characteristics: $\mathrm{pH}_{\text {in water }}=7.1$; organic matter $=0.2 \mathrm{dag} \mathrm{\textrm {kg } ^ { - 1 }} ; \mathrm{P}_{\text {Mehlich I }}$ $=24.1 \mathrm{mg} \mathrm{dm}{ }^{-3} ; \mathrm{K}=70 \mathrm{mg} \mathrm{dm}{ }^{-3} ; \mathrm{Ca}^{2+}=1.6 \mathrm{cmol}_{\mathrm{c}} \mathrm{dm}^{-3} ; \mathrm{Mg}^{2+}=0.5 \mathrm{cmol}_{\mathrm{c}} \mathrm{dm}^{-3}$. The soil was autoclaved three times at $120^{\circ} \mathrm{C}$ for 40 minutes.

For incorporation of treatments, the doses of organic compost and additional treatments were placed in separate $5 \mathrm{~L}$ plastic bags together with soil from each parcel. Bags were closed and manually stirred until complete homogenization, then returned to the pots. We opened four equidistant holes $\pm 5 \mathrm{~cm}$ depth in the central area of each pot, to which we added $5 \mathrm{ml}$ of water containing a total of 5,000 eggs plus second stage juveniles $\left(\mathrm{J}_{2}\right)$ of $M$. javanica. Eggs of M. javanica were obtained from pure populations of nematodes collected from tomato roots of Santa Cruz group grown in greenhouse using a modified Hussey and Barker technique (Bonetti \& Ferraz, 1981).

Soil remained wet for five days and then we transplanted a 21-day-old seedling of okra plant 'Santa Cruz' in each pot. As basic fertilization, all treatments received $200 \mathrm{mg} \mathrm{kg}^{-1}$ of P (single superphosphate) and $300 \mathrm{mg} \mathrm{kg}^{-1}$ of $\mathrm{K}$ (potassium chloride). Chemical fertilizing was parceled in three times. Irrigation was performed daily, keeping the soil constantly moist.

Plants were grown for 60 days and then we evaluated height of plants, shoot dry weight, fresh root weight, and variables related to reproduction of M. javanica: number of egg masses, galls and eggs per gram of root, and number of second stage juveniles $\left(\mathrm{J}_{2}\right)$ in the soil. We also evaluated reproduction factor (RF), which is the ratio between final population at 60 days (number of eggs at the root) and initial population (number of inoculated eggs) (Oostenbrink, 1966). 
Plant roots were rinsed in water and dipping in phloxine $\mathrm{B}\left(15 \mathrm{mg} \mathrm{L}^{-1}\right.$ phloxine) for visual count of eggs masses and galls. Then roots were cut into pieces of approximately $5 \mathrm{~mm}$ and subjected to egg extraction by the Hussey and Barker technique (1973) modified by Bonetti and Ferraz (1981). For number of $\mathrm{J}_{2}$ in the soil, samples 200 $\mathrm{cm}^{3}$ were processed through of technique of Jenkins (1964). Eggs and $\mathrm{J}_{2}$ of M. javanica were quantified in Peters counting chamber in inverted objective microscope. Number of galls, egg masses and eggs of M. javanica found in the roots were divided by each root weight to obtain the nematode variables per root gram.

In order to verify the assumptions of the analyses of variance, data from all quantitative variables were subjected to the Shapiro Wilk test. In case of significance of the test, data were transformed to $\sqrt{\mathrm{x}+1}$. A joint analyses of data over time was performed to check whether there was a difference between trials of a same experiment. If there was no significance between trials of a same experiment, we obtained their mean in order to carry out the analyses of variance (ANOVA). The variables obtained in trials were therefore subjected to ANOVA following the experimental desing used. When the variables were significant in the F test, they were subjected to the Scott-knott test at 5\% probability and adjustment in regression models using the statistical software $\mathrm{R}$ 3.1.3. The means of controls were compared with other treatments by Dunnett's test at $5 \%$.

\section{Results and Discussion}

Doses positively influenced plant height, shoot dry weight and root weight, which increased linearly with an increasing amount of organic material incorporated into the soil (Figure 1). The increase in plant development was directly proportional to the compost dose, with an increase of $15.6 \%$ in plant height, $35.1 \%$ in shoot weight, and $36.1 \%$ in root weight with a $30 \mathrm{~g} \mathrm{dm}^{-3}$ dose in relation to the zero-dose control (Figure 1).
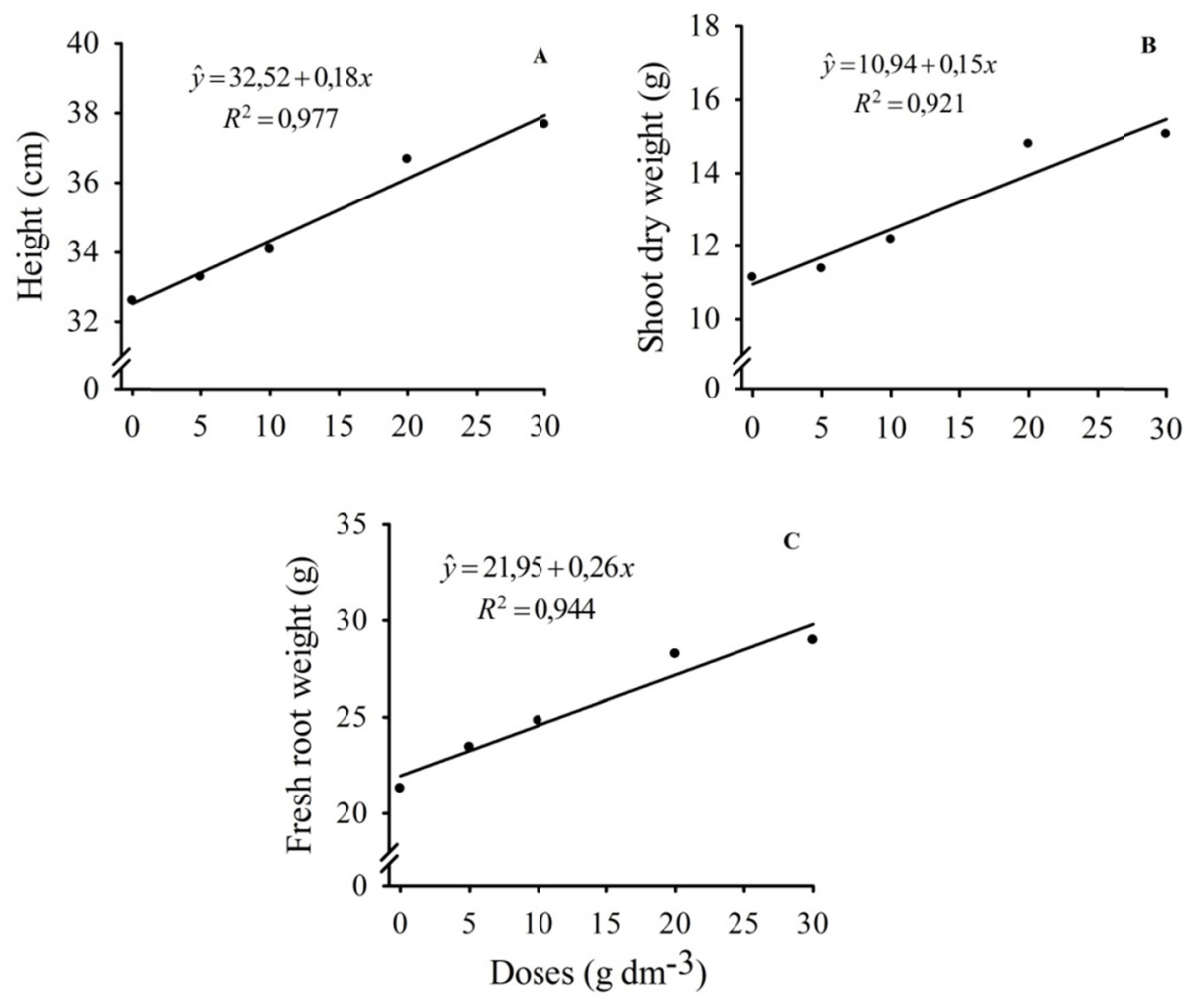

Figure 1. Plant height, shoot dry weight, and fresh root weight of okra plants grown in soil with addition of different doses of organic compost and inoculated with Meloidogyne javanica

Despite the linear effect for plant development the optimum doses were 20 and $30 \mathrm{~g} \mathrm{dm}^{-3}$, which promoted a greater shoot development compared to those observed in the controls (Table 2). The highest dose increased the dry weight by $20.9 \%$ and $35.1 \%$ and root weight by $23.9 \%$ and $24.4 \%$ compared to the increase with manure and mineral fertilizations, respectively. 
Table 2. Mean of variables: plant height, shoot dry weight (SDW) and root weight (RW) of okra plants grown in soil with addition of different doses of organic compost and infested with Meloidogyne javanica

\begin{tabular}{llll}
\hline Doses $(\mathrm{g})$ & Height $(\mathrm{cm})$ & Shoot dry weight $(\mathrm{g})$ & Root weight $(\mathrm{g})$ \\
\hline 0 & $32.6^{\mathrm{x}}$ & 11.1 & 21.3 \\
5 & 33.3 & 11.4 & 23.4 \\
10 & 34.1 & 12.1 & 24.8 \\
20 & 36.7 & $14.8^{\mathrm{xy}}$ & $28.2^{\mathrm{xy}}$ \\
30 & 37.7 & $15.0^{\mathrm{xy}}$ & $29.0^{\mathrm{xy}}$ \\
$\mathrm{CV}(\%)$ & 10.0 & 14.0 & $14.2^{2}$ \\
Manure & 36.8 & 12.4 & 23.4 \\
Mineral & 33.9 & 11.1 & 23.3 \\
\hline
\end{tabular}

Note. Means followed by letters $\mathrm{x}$ and $\mathrm{y}$ differ significantly from additional treatments with manure and mineral fertilizer respectively by Dunnett's test at $5 \%$.

A nutrient supply is a prerequisite for expressing plant growth potential. The higher plant development provided by the compost compared to mineral fertilizer could be due to the presence of essential elements (macro and micronutrients) in the organic compost. Furthermore, some authors explain that the nutritional effect alone can not completely explain the performance of organic composts, thus other factors, such as the absence of phytotoxicity, increased population of microorganism suseful to the soil, and improvement of soil physical properties-which increase soil moisture retention-should also be considered (Pane et al., 2015; Sahu et al., 2018).

Doses of 5 and $10 \mathrm{~g} \mathrm{dm}^{-3}$ can also be used to replace mineral fertilizer and manure, as there was no significant difference between these the effects of doses and those of mineral fertilization (Table 2). Thus, pequi waste organic composts are an attractive alternative, as they provided similar or higher results to those of chemical fertilizer.

The composting of pequi waste proved to be a viable technique for plant development, unlike the powdering of pequi waste, as evaluated by Ribeiro et al. (2012) on tomato crops, which proved toxic to plants. The absence of any phytotoxic effects in this study may be due to composting, as most substances potentially toxic to plants are eliminated during the process (Ait Baddi et al., 2004; Raj \& Antil, 2011).

The incorporation of organic compost with pequi peel into the soil provided a significant reduction in the population of $M$. javanica in okra plant roots $(p<0.05)$. The number of galls, egg mass, eggs per gram of root, and reproduction factor decreased linearly with an increasing concentration of organic compost in the soil (Figure 2). 

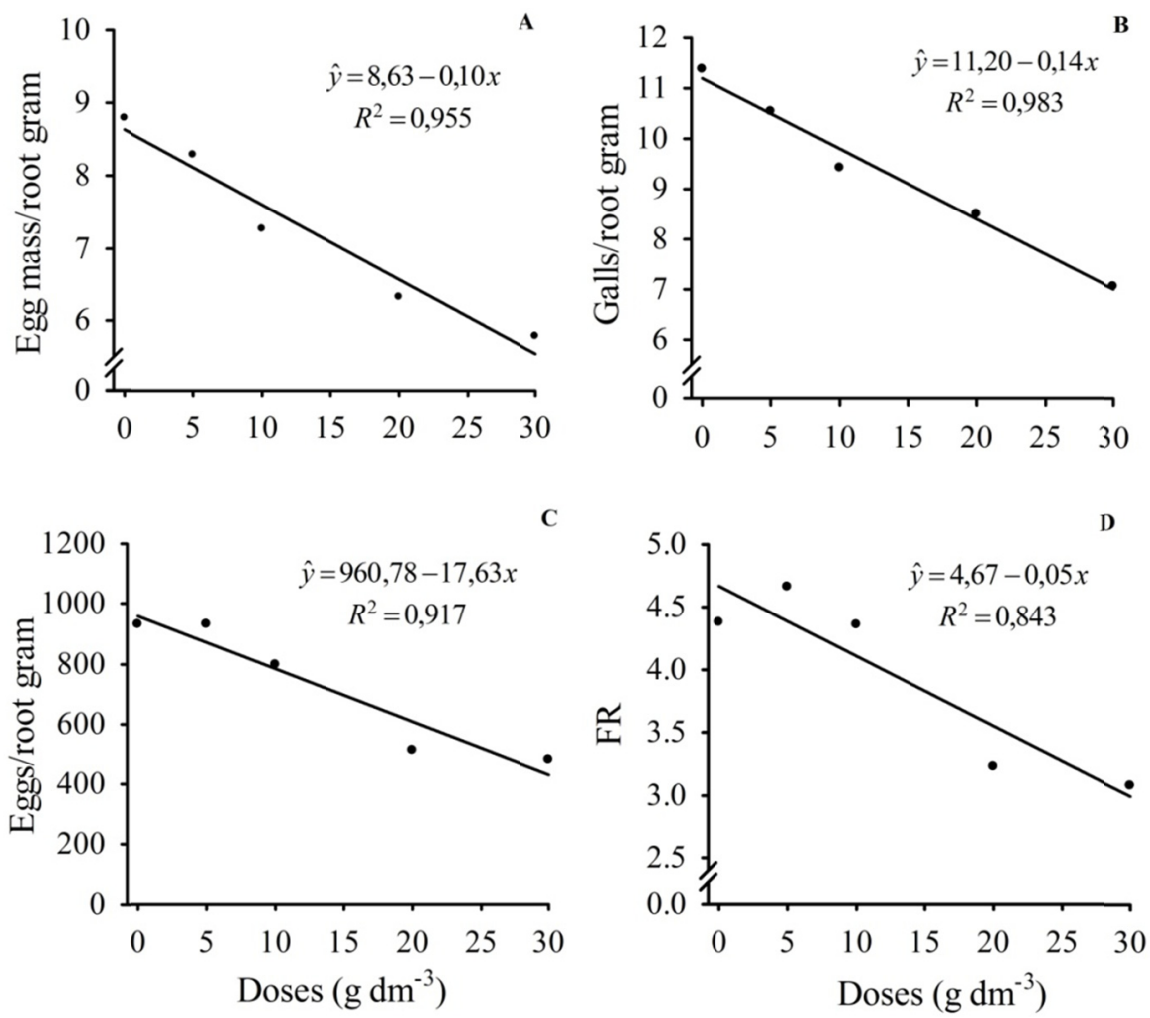

Figure 2. Number of galls, egg mass and eggs of Meloidogyne javanica per root gram of okra plants and reproduction factor (RF) in non-treated soil (0) and soil treated with 5, 10, 20 and $30 \mathrm{~g} \mathrm{dm}^{-3}$ of organic compost of pequi waste

Reductions of $38.05 \%, 27.98 \%, 48.42 \%$, and $29.5 \%$ were observed in the galls, egg mass, eggs per gram of root and reproduction factor respectively with dose $30 \mathrm{~g} \mathrm{dm}^{-3}$ in relation to the zero-dose. Therefore, the compost can interfere with host-pathogen interactions, stimulate root system growth, and increase the prevention to new infestations, thus reducing the development of $M$. javanica.

Shepherd (1979) considers the amount of eggs as the main criterion for evaluating nematode reproduction. Based on this statement, 20 and $30 \mathrm{~g} \mathrm{dm}^{-3}$ doses of organic fertillizer were more effective for reducing number of eggs per gram of root and reproduction factor than mineral fertilizer (Table 3). There were reductions of $82 \%$ and $86 \%$ in the number of eggs per gram of root and $91 \%$ and $95 \%$ in the reproduction factor with the incorporation of 20 and $30 \mathrm{~g} \mathrm{dm}^{-3}$ of compost, respectively, to those with mineral fertilization.

Table 3. Mean of nematode variables: number of galls per root gram, number of eggs per root and per root gram, and reproduction factor (RF) of Meloidogyne javanica in okra plants grown in soil with addition of different doses of organic compost of pequi waste

\begin{tabular}{|c|c|c|c|}
\hline Doses & Galls & Eggs & Reproduction factor \\
\hline 0 & $11.4^{x}$ & $933.2^{x}$ & 4.4 \\
\hline 5 & $10.5^{x}$ & $933.5^{x}$ & $4.7^{x}$ \\
\hline 10 & 9.4 & 797.7 & 4.4 \\
\hline 20 & 8.5 & $512.1^{\mathrm{y}}$ & $3.2^{\mathrm{y}}$ \\
\hline 30 & $7.0^{\mathrm{y}}$ & $481.2^{\mathrm{y}}$ & $3.1^{\mathrm{y}}$ \\
\hline $\mathrm{CV}(\%)$ & 36.3 & 33.5 & 34.2 \\
\hline Manure & 8.5 & 641.2 & 3.4 \\
\hline Mineral & 9.7 & 925.7 & 4.6 \\
\hline
\end{tabular}

Note. Means followed by letters $\mathrm{x}$ and $\mathrm{y}$ differ significantly from additional treatments with manure and mineral fertilizer respectively by Dunnett's test at $5 \%$. 
Reductions in the number of eggs and reproduction factor promoted by the pequi waste organic compost demonstrates its nematicidal activity. In fact, Ribeiro et al. (2012) reported the nematicidal effect of pequi when evaluating the effects its peel powder and mesocarp on the control of M. javanica. A incorporation of peel plus mesocarp of the dried and ground pequi to the soil sharply reduced the number of galls and egg mass of $M$. javanica in the roots of tomatoes grown in a greenhouse. The authors also reported a significant reduction inhatching and increased mortality of $M$. javanica $\mathrm{J}_{2}$ in different concentrations of pequi peel extract in vitro tests.

The low reproduction of nematodes in this study was probably due to secondary substances found in pequipeel, such as phenolic compounds, steroids, triterpenes, anthraquinones, flavonoid heterosides, saponin heterosides, condensed tannins, hydrolyzable tannins, and sugars (Perez, 2004). Some of these substances, such as terpene compounds-sand flavonoid glycosides, have proven nematicidal activity and can discourage nematode development (Ferraz et al., 2010; Du et al., 2011; Khan et al., 2017).

Several studies have reported tannin compounds as major metabolites responsible for plant defense to pathogens. According to Santos and Mello (1999), tannins play an important role in enzyme inactivation and growth inhibition in certain microorganisms. Some studies have shown that tannins reduce the hatching rate, inactivate $\mathrm{J}_{2}$ of Meloidogyne spp. and reduce the number of galls (Maistrello et al., 2010; Fonseca et al., 2017).

Other authors also found satisfactory results with the incorporation of organic matter into the soil to control nematodes, which result from secondary compounds whether pre-existing or generated during decomposition process. Neves et al. (2007) found considerable a considerable reduction in the population of M. javanica when the leaves and stalks of crucifers were incorporated into the soil. The results were due to sulfur compounds released during the processof waste decomposition.

In addition to the action of secondary compounds, mechanisms of action against nematodes associated with the incorporation of organic material into the soil are in some cases related to the improvement of the physical and chemical characteristics of the soil. This results in better development of the plants, which become more tolerant to parasitism (Stirling, 1991).

Compost dose is an important factor for reducing the intensity of plant nematodes, as confirmed in several studies in which increasing doses of organic matter was closely related to increased suppression of plant-parasitic nematodes (Nico et al., 2004; Renco et al., 2010). In this study, 20 and $30 \mathrm{~g} \mathrm{dm}^{-3}$ doses of organic compost were effective at controlling nematodes and plant development. Considering the application in total area and incorporation at $20 \mathrm{~cm}$ depth, such doses would be equivalent to 40 and $60 \mathrm{t} \mathrm{ha}^{-1}$. This amount of compost is within the recommended levels, as quantities commonly used in organic fertilizers vary from 10-50 $\mathrm{tha}^{-1}$ during the growth cycle of vegetables (Santos, 2005).

The incorporation of pequi waste organic compost at doses of 20 and $30 \mathrm{~g} \mathrm{dm}^{-3}$ increases plant growth and reduces the reproduction of $M$. javanica in okra plants.

\section{Acknowledgements}

The authors gratefully acknowledge the financial support for conducting this study provided by FAPEMIG (Research Support Foundation of Minas Gerais).

\section{References}

Ait Baddi, G., Alburquerque, J. A., Gonzalves, J., Cegara, J., \& Hafidi, M. (2004). Chemical and spectroscopic analyses of organic matter transformation during composting of olive mill wastes. International Biodeterioration Biodegradation, 54, 39-44. https://doi.org/10.1016/j.ibiod.2003.12.004

Bonetti, J. I. S., \& Ferraz, S. (1981). Modificação do método de Hussey e Barker para extração de ovos de Meloidogyne exigua de cafeeiro. Fitopatologia Brasileira, 6, 553-554.

Campos, V. P. (1995). Doenças causadas por nematoides em alcachofra, alface, chicória, morango e quiabo. Informe Agropecuário, 17, 17-22.

Devi, S. T. H., \& Das, D. (2016). Effect of organic amendments on root-knot nematode (Meloidogyne incognita) in cucumber. Pest Management in Horticultural Ecosystems, 22, 176-181.

Du, S. S., Zhang, H. M., Bai, C. Q., Wang, C. F., Liu, Q. Z., Liu, Z. L., ... Deng, Z. W. (2011). Nematicidal flavone-C-glycosides against the root-knot nematode (Meloidogyne incognita) from Arisaemae rubescens Tubers. Molecules, 16, 5079-5086. https://doi.org/10.3390/molecules 16065079 
Ferraz, S., Freitas, L. G., Lopes, E. A., \& Dias-Arieira, C. R. (2010). Manejo sustentável de fitonematoides (p. 306). Viçosa: UFV.

Ferreira, D. F. (2011). SISVAR: A computer statistical analysis system. Ciência e Agrotecnologia, 35, $1039-1042$. https://doi.org/10.1590/S1413-70542011000600001

Fonseca, L. W., Almeida, F. A., Leite, M. L. T., Rambo, A. P. P., Oliveira, A. M., Carvalho, R. M., ... Petter, F. A. (2017). Bioactivity of aqueous extracts of Anadenanthera macrocarpa to Meloidogyne incognita in cotton crop. Australian Journal of Crop Science, 11, 156-161. https://doi.org/10.21475/ajcs.17.11.02.p203

Giné, A., Bonmati, M., Sarro, A., Stchiegel, A., Valero, J., Ornat, C., ... Sorribas, F. J. (2013). Natural occurrence of fungal egg parasites of root-knot nematodes, Meloidogyne spp. in organic and integrated vegetable production systems in Spain. Biocontrol, 58, 407-4016. https://doi.org/10.1007/s10526-012-9495-6

Jenkins, W. R. (1964). A rapid centrifugal- flotation technique for separating nematodes from soil. Plant Disease Reporter, 48, 692.

Khan, A., Asif, M., Tariq, M., Rehman, B., Parihar, K., \& Siddiqui, M. A. (2017). Phytochemical investigation, nematostatic and nematicidal potential of wedds extract against the root-knot nematode, Meloidogyne incognita in vitro. Asian Journal of Biological Sciences, 10, 38-46. https://doi.org/10.3923/ajbs.2017.38.46

Kiehl, E. J. (1985). Fertilizantes orgânicos. São Paulo, SP: Ceres.

Luambano, N. D., Manzanilla-López, R. H., Kimenju, J. W., Powers, S. J., Narla, R. D. N., Wanjohi, W. J., \& Kerry, B. R. (2015). Effect of temperature, $\mathrm{pH}$, carbon and nitrogen ratios on the parasitic activity of Pochonia chlamydosporia on Meloidogyne incognita. Biological Control, 80, 23-29. https://doi.org/ 10.1016/j.biocontrol.2014.09.003

Maistrello, L., Vaccari, G., \& Sasanelli, N. (2010). Effect of chestnut tannins on the root-knot nematode Meloidogyne javanica. Helminthologica, 47, 48-57. https://doi.org/10.2478/s11687-010-008-9

Naz, I., Palomares-rius, J. E., Saifullah, B. V., Khan, M. R., \& Ali, S. (2013). In vitro and in planta nematicidal activity of Fumaria parviflora (Fumariaceae) against the southern root-knot nematode Meloidogyne incognita. Plant Pathology, 62, 943-952. https://doi.org/10.1111/j.1365-3059.2012.02682.x

Neves, W. S., Freitas, L. G., Coutinho, M. M., Parreira, D. F., Ferraz, S., \& Costa, M. D. (2007). Biofumigação do solo com espécies de brássicas para o controle de Meloidogyne javanica. Nematologia Brasileira, 31, 195-201.

Nico, A. I., Jiménez-Díaz, R. M., \& Castillo, P. (2004). Control of root-knot nematodes by composted agro-industrial wastes in potting mixtures. Crop Protection, 23, 581-587. https://doi.org/10.1016/j.cropro. 2003.11.005

Nile, A. S., Nile, S. H., Keum, Y. S., Kim, D. H., Venkidasamy, B., \& Ramalingam, S. (2018). Nematicidal potential and specific enzyme activity enhancement potential of neem (Azadirachta indica A. Juss.). Environmental Sicence and Pollution Research, 25, 4204-4213. https://doi.org/10.1007/s11356-017-0821-5

Oka, I. (2010). Mechanisms of nematode suppression by organic soil amendments-A review. Applied Soil Ecology, 44, 101-115. https://doi.org/10.1016/j.apsoil.2009.11.003

Oliveira, R. D. L., Silva, M. B., Aguiar, N. D. C., Bérgamo, F. L. K., Costa, A. S. V., \& Prezotti, L. (2007). Nematofauna associada à cultura do quiabo na região leste de Minas Gerais. Horticultura Brasileira, 25, 88-93. httpS://doi.org/10.1590/S0102-05362007000100017

Oostenbrink, M. (1966). Major characteristics of the relation between nematodes and plants. Mededelingen, 66, $1-46$.

Osei, K., Fening, J. O., Gowen, S. R., \& Jama, A. (2010). The potential of four non traditional legumes in suppressing the population of nematodes in two Ghanaian soils. Journal of Soil Science and Environmental Management, 1, 63-68.

Pane, C., Celano, G., Piccolo, A., Villecco, D., Spaccini, R., Palese, A. M., \& Zaccardelli, M. (2015). Effects of on-farm composted tomato residues on soil biological activity and yields in a tomato cropping system. Chemical and Biological Technologies in Agriculture, 2, 1-13. https://doi.org/10.1186/s40538-014-0026-9

Plácido, G. R., Silva, R. M., Silva, M. A. P., Caliari, M., Belisário, C. M., \& Cagnin, C. (2015). Physical and chemical parameters, total phenols and the antioxidant activity of Pequi (Caryocar brasiliense Camb.). African Journal of Agricultural Research, 10, 534-542. https://doi.org/10.5897/AJAR2014. 9364 
Raj, D., \& Antil, R. S. (2011). Evaluation of maturity and stability parameters of composts prepared from agro-industrial wastes. Bioresource Technology, 102, 2868-2873. https://10.1016/j.biortech.2010.10.077

Renco, M., Sasanelli, N., D’Addabbo, T., \& Papajová, I. (2010). Soil nematode community changes associated with compost amendments. Nematology, 12, 681-692. https://doi.org/10.1163/138855409X12584413 195491

Ribeiro, H. B., Ribeiro, R. C. F., Xavier, A. A., Campos, V. P., Dias-Arieira, C. R., \& Mizobutsi, E. H. (2012). Resíduos de frutos de pequi no controle do nematoide das galhas em tomateiro. Horticultura Brasileira, 30, 453-458. https://doi.org/10.1590/S0102-05362012000300016

Sahu, M. K. P., \& Dash, B. (2018). Management of Root Knot Nematode (Meloidogyne incognita) in Tomato (cv. Pusa ruby) using Different Oil Cakes Sasmita. International Journal of Current Mocrobiology and Applied Sciences, 7, 2527-2532. https://doi.org/10.20546/ijcmas.2018.703.292

Santos, R. H. S. (2005). Olericultura orgânica. In P. C. R. Fontes (Ed.), Olericultura: Teoria e prática (pp. 249-276). Viçosa: UFV.

Santos, S. C., \& Mello, J. C. P. (1999). Taninos. In C. M. O. Simoes (Ed.), Farmacognosia da planta ao medicamento (pp. 517-544). Porto Alegre, Florianópolis: Editora da UFSC.

Shepherd, R. L. (1979). A quantitative technique for evaluating cotton for roott-knot nematode resistance. Phytopathology, 69, 427-430. https://doi.org/10.1094/Phyto-69-427

Stirling, G. R. (1991). Biological control of plant parasitic nematodes: Progress, problems and perspects. CAB International, Wallingford, UK. https://doi.org/10.1093/ee/22.4.881

\section{Copyrights}

Copyright for this article is retained by the author(s), with first publication rights granted to the journal.

This is an open-access article distributed under the terms and conditions of the Creative Commons Attribution license (http://creativecommons.org/licenses/by/4.0/). 